\title{
Book Review Atheist Manifesto
}

\section{Book Review of}

Atheist Manifesto: The Case Against Christianity, Judaism and Islam, by Michel Onfray (2007) Arcade Publishing, Inc., New York, USA.

This is a grandiose, pressured, verbose, distorted, agitated, psycho-sociopathic book which strains credibility that it was ever printed. It is a word salad about atheism which only the megalomaniac author claims to really understand. He presents himself as the first real atheist, all prior atheists not being atheistic enough, such that the Masons, according to Onfray, were really "christian atheists." He offers "atheology"... as his sect of the SA religion. His is not just nihilism but a way of thinking, he claims, without religion -- calling real religions to be metaphysical ontological diseases.

Onfray is heavy into Freudism and therefore grandiose solipsisms pervade: Atheism is not therapy but restored mental health (Pg. 4), i.e., psychoanalytic gobbledegook "mental health" pretending to deal with reality.

Just as psychoanalysts often treat others in order to avoid questioning themselves too closely about their own weaknesses, so the vicars of monotheist gods foist their vision of the world on the faithful -- and day by day their own convictions become more secure (Pg. 3). (And "hoist by one's own petard!" as Onfray does the same to secure his own convictions).

My atheism leaps to life when private belief becomes a public matter, when in the name of a personal mental pathology we organize a world for others (Pg. 3).

And so he proceeds to do exactly that. Atheology is "a physics of metaphysics, a true theory of man's inherent nature (immanence) and materialist ontology" (Pg. 8).

A dead god would imply a vanquished void. We are light years away from such ontological progress... (Pg. 13).

Onfray obviously hates all he has learned. He has the answer for everything. He conflates better than any atheist ever by his own admission. He provides an unscholarly rant, the promotion of which is an intellectual crime against human reason. Revealing his intelligence, he maintains his Marxism in spite of its obvious historical failure. He has no problem with pedophilia and almost anything else:

The hedonist contract -- nothing could be more immanent -legitimatizes all intersubjectivity, conditions all thought and action, dispenses utterly with God, religion, and priests...It is an ethic without transcendent obligation or sanctions (Pg. 58).

Onfray offers no rational, reasonable basis to prohibit any sort of sexual activity or just about anything else. So, after declaring

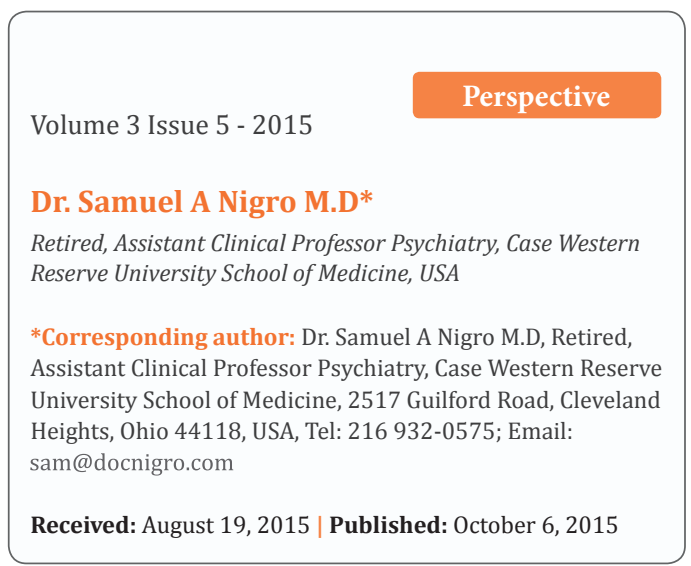

"anything goes" he proceeds to condemn other people doing what he does not like. A few glimpses of this madman's homilies on religion: "Monotheism's somber vision" (Pg. 65); "Down with intelligence" (Pg. 67); "The book bias against books" (Pg. 78); "Hatred of science" (Pg. 81); "The detesting of women" (Pg. 102); "Ravings of a hysteric" (St. Paul)(Pg. 131); "In praise of slavery" (Pg. 137); "Hitler, St. John's disciple" (Pg. 166); "The Vatican admired Adolf Hitler" (Pg. 184); and "Jesus at Hiroshima" (Pg. 191).

The author is a bold liar, judging without any sense of decency or open mindedness, distorting history, propagandizing and filled with culpable ignorance. He is a suggestibility expert and provides non-being to all his readers. He is a mean spirited annihilating mocker of anything and everything he doesn't understand or like. He is a putdown artist, verbose, loud, striving to be a celebrity which means that he is a fake from start to finish. That is Onfray at his best.

As a psychiatrist, I believe it is more charitable to see Onfray as a mentally ill man: And if anything goes, he really ought to release his psychiatric treatment record as such to find something that really is a failure. If nothing matters, Onfray should tell us all. Some of his verbose sections are almost incomprehensible filled with distractions and loose associations. His "In praise of slavery" (Pg. 137) is pure psychobabble having little to do with slavery. It is frightening, that this sort of stuff makes it into print and will be praised, no doubt, by birds of a feather.

The invention of an afterlife would not matter so much were it not purchased at so high a price: disregard of the real, hence willful neglect of the only world there is. While religion is often at variance with immanence, with man's inherent nature, atheism is in harmony with the earth -- life's other name (Pg. xvi).

Onfray's coherence must be the result of an editor who 
obviously gave up many times throughout the book because of a lot of semi-delusional manic like ramblings break through in a pseudo-sophisticated way. This book does nothing except prove how suggestible people are and that the best definition of Original Sin is "suggestibility" or being snake bit and needing a lot of medicines. 